\title{
ALLUVIUM: EARTHEN CONSTRUCTION IN FUTURE URBAN AREA
}

\author{
Julia Tourtelot ${ }^{1,2}$, Loren Masson ${ }^{2,3}$, Myriam Duc ${ }^{3}$, Jeanne-Sylvine Guedon ${ }^{3}$, \\ Laurent Brochard ${ }^{1}$, Matthieu Vandamme ${ }^{1}$, Robert Le Roy ${ }^{4}$, Erwan Hamard ${ }^{3}$, \\ Chloé Fourdrin ${ }^{5}$, Thomas Barrée, Jean-Didier Mertz ${ }^{2,7}$, Ann Bourgès ${ }^{2,7}$, \\ Emmanuel Keita ${ }^{1},{ }^{*}$
}

${ }^{1}$ Laboratoire Navier, Univ. Paris-Est, Champs-sur-Marne, France

${ }^{2}$ LRMH, 77420 Champs-sur-Marne, France

${ }^{3}$ IFSTTAR, Univ. Paris-Est, Champs-sur-Marne, France

${ }^{4}$ ENSAPM/GSA, Univ. Paris-Est, Champs-sur-Marne, France

${ }^{5}$ LGE, Univ. Paris-Est Marne La Vallée, Champs-sur-Marne, France

${ }^{6}$ ERUDITE, Univ. Paris-Est Marne La Valleee, Champs-sur-Marne, France

${ }^{7}$ CRC-USR 3224, Sorbonne Univ., Muséum national d'Histoire naturelle, Ministère de la Culture et de la Communication, CNRS, Univ. Paris-Est, Champs-sur-Marne, France

*emmanuel.keita@ifsttar.fr

\begin{abstract}
Major component of raw earth construction, natural and reusable material, clays have amazing properties. They act as a binder in earthen materials and have enabled the building of cities since the beginning of the Neolithic revolution. However, their high sensitivity to the environment impacts the durability of clay-rich materials such as earthen ones. ALLUVIUM is a project supported by the I-Site FUTURE from the Paris Est University, and brings together economists, architects, researchers of historical sites as well as engineers to develop, test and apply at different scales reinforced earthen materials. The properties improvement is obtained by the addition of biopolymers or surfactants. The project aims to demonstrate the potential of earthen construction in future urban area as well as in the conservation of a traditional built cultural heritage.
\end{abstract}

Keywords: Earthen materials, biopolymer, surfactant 


\section{INTRODUCTION}

Earth has been used as a building material for eleven millennia and today, earthen architectural heritage is widely present in each continent. At least one third of the world population lives in earthen buildings (Doat et al., 1979; Dethier, 1981). 20\% of the World Heritage properties are built partially or entirely with earth. In Europe, most of the earthen built heritage is still inhabited. This is the case of several historic city centers (Strasbourg, Rennes, Rouen, Provins, Tours in France) but also rural territories like Tierra de Campos in Spain; Devon region in the UK; wide regions of Hungary and Romania. In France, 15\% of the national architectural heritage is built with earth, that is around 2400000 dwellings (Guillaud, 2008). In Europe, the existence of around 8 million earth buildings is estimated.

In the Western countries, the construction sector consumes currently a large volume of natural resources and is responsible for about $50 \%$ of wastes production. Among this large amount of wastes around $75 \%$ are soils and stones. These wastes have a negative environmental impact and it is increasingly difficult to find suitable landfill areas. The political demand thus promotes waste recycling, circular economy and encourages producers to find a market for construction wastes. In this context earth construction provides a relevant option.

Earthen buildings also decrease the impact of the construction sector on climate change. Indeed, the sector represents about a third of the World total energy consumption, and it is one of the main contributors to climate change. The development of appropriate technologies for sustainable construction is one of the most pressing issues faced by this sector both in developed and developing countries. Earthen construction is a sustainable way of construction which represents an opportunity and challenge for architects. Famous architects (Wang Shu for the China Academy of Art guest house, Herzog and Demeuron for the industrial hall in Lofon, Switzerland) have produced iconic projects in earthen materials, leading to a new dynamism in architecture (Kapfinger and Sauer, no date).

Finally, earthen constructions are beneficial for health and well-being of the occupants. Earthen walls are known for their high thermal mass and hygroscopicity enabling water phase changes, buffering outdoor temperature variations. They are able to accumulate solar energy during the day and restitute this energy during the night. These features provide to inhabitants of earthen buildings a good thermal comfort and more specifically during summer period. In addition earthen materials are able to rapidly adsorb a significant amount of water vapour and also to restitute water vapour in building indoor air. Moisture buffering of earthen materials is beneficial for health and well-being of the occupants.

\section{MAIN CHALLENGES}

Embodied energy together with operational energy of the building sector represent approximately $40 \%$ of global energy use. As a consequence, the building sector is a major producer of greenhouse gases contributing to climate change. As most effort is dedicated to operational energy, the next challenge for the building sector will be the reduction of embodied energy. The embodied energy of earth construction is very low 
compared to other materials conventionally used in construction. For example, embodied energy of a wall made of earth is about 20 times less than this of a hollow cinder block wall. As a consequence, earth construction has a very low carbon and energy footprint.

At the material scale, a large variety of clay-rich earth construction processes exists (Hamard et al., 2016). However cement or lime are used as stabilizer to improve mechanical strength and durability of earth walls. Nonetheless, the stabilisation of thick earthen walls, even at low percentage, consumes large amount of cement and prevents the reuse of the material at end of life. Lime and cement can sometimes create undesirable chemical transformations of soil colloid minerals, in particular by chemical reaction with clay minerals or salts. These chemical reactions can lead to the formation of new swelling minerals (e.g. ettringite) and cause severe damage. A strategy to avoid these complications is the use of additives without chemical reactions but improving the cohesion between clays and other soil colloids by surface interactions at the nanoscale. Some traditional earth-based plasters reinforced with various biopolymers have proven to be effective in terms of durability and water resistance (Achenza and Fenu, 2007; Fontaine and Anger, 2009), e.g. cellulose from rotted straw, starch from flours, polysaccharides from algae, albumin from egg whites, casein from milk, etc.

This novel approach provides low-energy stabilization solutions and it could be applied in the context of the Great Paris project. Indeed, 43 million tons of soils will be excavated in the next decade and will need valorization or disposal sites. In excavated materials, clay valorization is usually poor, as clay is often considered as detrimental in civil engineering because of its tendency to swell / shrink upon imbibition / drying. Yet, clay proves useful for impermeability. The potential use of clays and alluvium in buildings is a great opportunity (CRAterre, 2016).

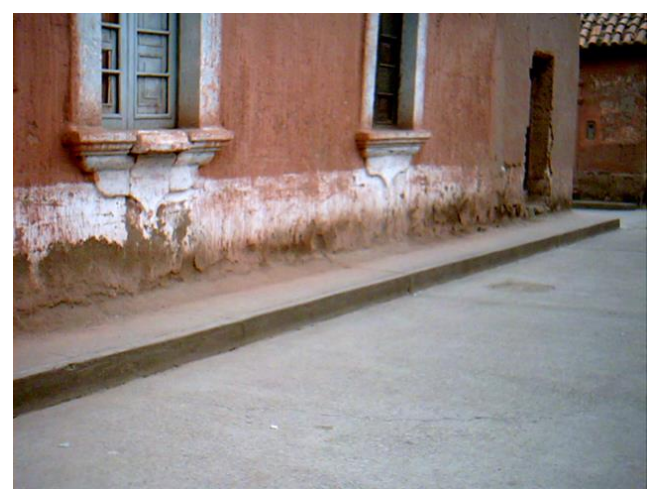

Figure 1: Unprotected earthen wall in Lampa (Peru) damaged by water flow. Credit: A. Bourgès

Furthermore, house walls in developing countries are mostly made of earthen bricks making them particularly vulnerable to rain and wind erosion (see Figure 1). New threats due to climate change are even increasing the vulnerability of earthen buildings (heavy rains, tempests with lateral winds, floods). As a result, the market addressing the conservation of earthen heritage is increasing. From a technical point of view, the protection of earth structures involves the application of surface protection techniques 
to slow down the erosion process on earth structures. Surface protection materials can be obtained by addition of various products to earth such as surfactant coupled with biopolymers, for an improved cohesion.

\section{INTERDISCIPLINARITY}

Researches based on a better understanding of the traditional knowledge will help develop techniques and materials to better meet professional and user expectations, provide a greater ease of use, improve compatibility with the structures and a greater resistance to the degradation factors. The ALLUVIUM project brings together a multidisciplinary team, gathering economists, architects, historic monuments researchers, geoscientists and civil engineers to develop new materials with predictable properties and behaviors, suitable for wide distribution while respecting the diversity of way of life in the town and on heritage, strongly linked with the sociocultural environments.

The evaluation of the economic impact of the development of a sustainable construction sector based on local earth bricks will help developing appropriate technologies to make raw earth bricks stable enough to be used in modern buildings.

\section{RESEARCH METHODOLOGY}

\section{Polymer-Clay Composite}

The techniques of earthen construction with biopolymer additives suffer from a lack of knowledge about their mechanisms of attachment to clay surfaces. It is generally accepted that organic macromolecules bridge mineral particles leading to aggregation, but nonionic macromolecules are very effective soil conditioners. Thus the role of ionicity remains unclear. The multi-scale analysis is essential, going through the understanding of system of attachment at the molecular scale, the structure of the material, its hydro-mechanical properties. By understanding the structure of the hybrid biopolymer-clay materials synthesized, we would have a better apprehension of their long-term behavior as construction materials.

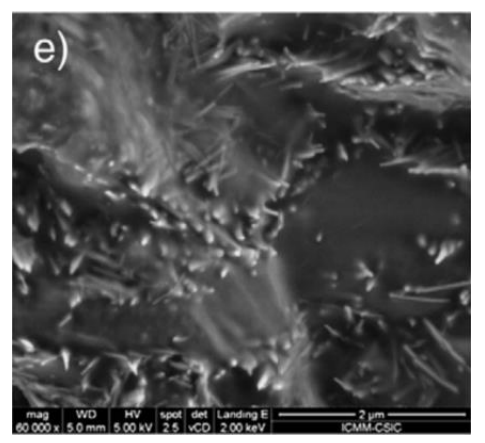

Figure 2: FE-SEM images of bionanocomposites of starch and clay minerals from (Alcântara et al., 2014) 
In order to study these fixation mechanisms of the bio-polymer (for example polysaccharides) on clay minerals, we used synthetic or purified clays (kaolinite, illite, montmorillonite) to insure the purity and uniformity of their surfaces.. In ALLUVIUM, the interactions between biopolymer, such as polysaccharides, and clays are investigated by means of different spectroscopic techniques like $\mu$-spectroscopy Raman mapping, infrared spectroscopy and spectrofluorometry (Margarita Darder, Montserrat Colilla and Ruiz-Hitzky, 2003; Alcântara et al., 2014, Perez et al., 2016). Besides, regarding the swelling clays, the potential incorporation and organization of the biopolymers inside the interlayers are followed by X-Ray Diffraction. Images, chemical analysis and electron diffraction of the interface clay-biopolymer are performed with TEM at the IMPMC (UPMC, Paris) after preparation of FIB sections. The combination of these techniques enhances the understanding of the organization of the biopolymers inside the interlayer or at the surface of clay aggregates.

\section{Clay Stabilization by Surfactant}

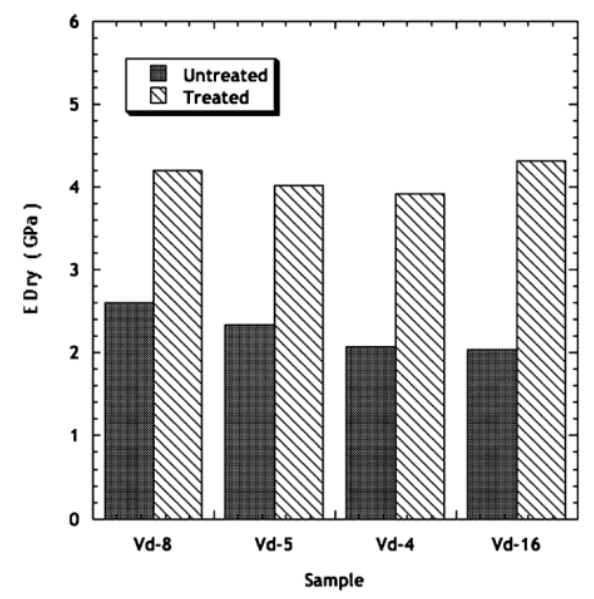

Figure 3: Effect of swelling inhibitors on the modulus of the Villarlod Molasse from (Jimenez Gonzalez and Scherer, 2004)

The sensitivity of clays to moisture generates swelling/shrinkage constraints in stone or in raw earth materials. These hydro-mechanical solicitations are at the origin of a loss of material (cracks and desquamation) that causes damage on structure. Parallel to the use of surface or mass water repellent, inducing a lower surface tension of minerals, the preventive use of other surfactants should inhibit the deformations and reduce disorders (Snethlage and Wendler, 1990; Jimenez Gonzalez and Scherer, 2004). Current developed surfactant limits the accessibility of water to the clay nanoporosity, which suppress the crystalline swelling of clay and decrease the cation exchange capacity (CEC) of clay material. However, depending on the concentration of the surfactant, not only the water absorption coefficient of clay is impacted but also its shrinkage properties (measured with a unidirectional dilatometric monitoring of specimens) or its compressive strength. We develop a new approach consisting in 
adapting the concentration of the surfactant, to the CEC of the treated material. Other surfactants are formulated to optimize the mechanism according to the CEC of clays.

\section{Material Characterization}

The bio-polymers act as a binder in the earth matrix and may reinforce the cohesion of the material. This bio-stabilization should enhance the resistance to abrasion and to rain erosion, the mechanical resistance and reduce the sensitivity to water of earthen walls. However, as highlighted for cement or lime stabilization, the addition of a binder in the earth matrix may negatively impact the hydrothermal behavior of earthen walls. In order to assess the effect of bio-geo-polymers on earthen materials, mechanical and hydrothermal behavior are characterized. Its involves tests to measure uniaxial compressive strength, modulus (Vinceslas et al., no date), cohesion, hydric dilatation, bending stress (Hamard et al., 2013), abrasion (Mesbah et al., 2000) and thermal conductivity.

\section{Socio-Economic Impact of Earth Construction}

The development of new (or rediscovery of old) technologies requires considerable investment and a self-sustaining market to create a real breakthrough in consumption habits. The economic evaluation proposed in this project offers an inquiry into the question of the economic sustainability of earthen construction methods in in France and Burkina Faso in order to cover both developed and developing countries.

Empirical evidence shows that the construction sector has a strong demand for skilled and unskilled local labor, playing a crucial role in the dynamism of the local economy. In France, we estimate that the construction of one new home creates 1.6 new jobs. The effect found is even higher in developing countries; a detailed analysis of the housing sector in India shows that every 1,300 euros invested in the housing sector creates 2.69 new jobs in the economy (NCAER, 2014). Furthermore, the study estimates that one additional euro of final demand for housing translates into 5.11 euros of additional revenues for the economy.

We estimate similar effects in the case of earthen constructions in Europe and Sahel. We expect stronger returns on investment since earthen construction methods are very labor intensive, especially in Sahel. Also we evaluate the impact of earthen housing on other factors such as house comfort (temperature, noise, and security), the impact on local masons and their business and the valorization of clay quarries by the local community. In order to conduct this analysis, we collect data on earthen constructions in France and work in partnership with the Nubian Vault which promotes earthen housing in the Sahel region and trains local masons to the appropriate construction techniques.

\section{CONCLUSION}

ALLUVIUM project brings together economists, architects, researchers of historical sites as well as engineers to develop, test and apply at different scales reinforced earthen materials. The properties improvement is obtained by the addition of 
biopolymers or surfactants. The project aims to demonstrate the potential of earthen construction in future urban area as well as in the conservation of a traditional built cultural heritage. The findings will be of practical usage in the development of building solutions using excavated soils.

\section{ACKNOWLEDGEMENT}

ALLUVIUM is a project supported by the I-Site FUTURE from the Paris Est University and financed by the French National Research Agency and the "Programme Investissement d'Avenir".

\section{REFERENCES}

Achenza, M. and Fenu, L. (2007) 'On Earth Stabilization with Natural Polymers for Earth Masonry Construction', Materials and Structures, 39(1), pp. 21-27. doi: 10.1617/s11527-005-9000-0.

Alcântara, A. C. S. et al. (2014) 'Polysaccharide-fibrous clay bionanocomposites', Applied Clay Science, 96(96), pp. 2-8. doi: 10.1016/j.clay.2014.02.018.

CRAterre (2016) Excavated materials valorization-Société du Grand Paris.

Dethier, J. (1981) 'Des Architectures de terre ou l'Avenir d'une tradition millénaire', Centre Georges Pompidou, Paris.

Doat, P. et al. (1979) Construire en terre. Edited by Editions Alternatives et Parallèles. Paris. Available at:

https://www.abebooks.fr/servlet/BookDetailsPL?bi=16667721742\&searchurl=tn\%3 Dconstruire\%2Ben\%2Bterre\%26sortby\%3D17\%26an\%3Dcraterre\&cm_sp=snippet_-srp1-_title2 (Accessed: 9 November 2017).

Fontaine, L. and Anger, R. (2009) Bâtir en terre Du grain de sable à l'architecture. Belin.

Guillaud, H. (2008) Terra incognita: Discovering \& Preserving European Earthen Architecture. Argumentum. Available at:

https://books.google.fr/books/about/Terra_Incognita.html?id=UfkdPwAACAAJ\&red ir_esc $=y$ (Accessed: 9 November 2017).

Hamard, E. et al. (2013) 'A procedure to assess the suitability of plaster to protect vernacular earthen architecture', Journal of Cultural Heritage, 14(2), pp. 109-115. doi: 10.1016/j.culher.2012.04.005.

Hamard, E. et al. (2016) 'Cob, a vernacular earth construction process in the context 
of modern sustainable building', Building and Environment. Elsevier Ltd, pp. 103119. doi: 10.1016/j.buildenv.2016.06.009.

Jimenez Gonzalez, I. and Scherer, G. (2004) 'Effect of swelling inhibitors on the swelling and stress relaxation of clay bearing stones', Environmental Geology. Springer-Verlag, 46(3-4), pp. 364-377. doi: 10.1007/s00254-004-1038-8. Kapfinger, O. and Sauer, M. (no date) Martin Rauch, refined earth : construction \&amp; design with rammed earth. Edited by E. DETAIL.

Margarita Darder, Montserrat Colilla, and and Ruiz-Hitzky, E. (2003) 'Biopolymer-Clay Nanocomposites Based on Chitosan Intercalated in Montmorillonite'. American Chemical Society, 15(20), pp. 3774-3780. doi: 10.1021/CM0343047.

Mesbah, A. et al. (2000) 'Blocs de terre comprimée - Procédures d'essais'. Bruxelles (Belgium): CDE, Craterre, ENTPE, p. 121.

NCAER (2014) 'Impact of investments in the housing sector on GDP and employment in the Indian economy', National Council of Applied Economic Research.

Perez, A. et al. (2016) 'Bioalteration of synthetic Fe(III)-, Fe(II)-bearing basaltic glasses and Fe-free glass in the presence of the heterotrophic bacteria strain Pseudomonas aeruginosa : Impact of siderophores', Geochimica et Cosmochimica Acta, 188, pp. 147-162. doi: 10.1016/j.gca.2016.05.028.

Snethlage, R. and Wendler, E. (1990) 'Surfactants and Adherent Silicon Resins New Protective Agents for Natural Stone', MRS Proceedings. Cambridge University Press, 185, p. 193. doi: 10.1557/PROC-185-193.

Vinceslas, T. et al. (no date) 'Further development of a laboratory procedure to assess the mechanical performance of cob', Environmental Geotechnics. 